\title{
Availability of lysine in meat meal, meat and bone meal and blood meal as determined by the slope-ratio assay with growing pigs, rats and chicks and by chemical techniques
}

\author{
By E. S. BATTERHAM, R. F. LOWE AND R. E. DARNELL* \\ Department of Agriculture, Agricultural Research Centre, \\ Wollongbar, New South Wales 2480, Australia \\ AND E. J. MAJOR \\ Department of Agriculture, Agricultural Station, Seven Hills, \\ New South Wales 2147, Australia
}

(Received 17 July 1985 - Accepted 6 November 1985)

1. The availability of lysine in four meat meals (MMs), four meat and bone meals (MBMs) and two blood meals was determined using the slope-ratio assay with growing pigs, rats and chicks and with two chemical techniques.

2. The availability of lysine (proportion of total) in the eight MMs or MBMs ranged from 0.48 to 0.88 for pigs, from 0.49 to 0.88 for rats and from 0.68 to 0.88 for chicks. There was no apparent relation between the availability estimates for pigs, rats and chicks for the individual meals.

3. For the two blood meals, availability estimates were 1.03 and 1.13 for pigs, 0.81 and 0.80 for rats and 1.07 and 1.02 for chicks.

4. Values for the indirect and direct 1-fluoro-2,4-dinitrobenzene-' available'-lysine assays ranged from $0 \cdot 77$ to 0.88 and 0.78 to 0.93 respectively for the eight MMs and MBMs. There appeared to be no relation between these values and the pig estimates.

Previous work indicated that meat meal (MM) and meat and bone meal (MBM) were of low quality for pigs (Batterham et al. 1978) with an available lysine content (proportion of total) in MBM of 0.49 (Batterham et al. 1979). This low availability may be due to the composition of the material used to produce the meal (flesh, collagen and bone) or to processing conditions.

The low lysine availability in MBM for pigs was not detected by either the indirect- (Roach et al. 1967) or direct- (Carpenter, 1960) 1-fluoro-2,4-dinitrobenzene (FDNB)-'available'lysine assays (values of 0.84 and 0.79 respectively (Batterham et al. 1979)). However, the indirect-FDNB assay particularly is a precise assay, and values for MBMs vary from approximately 0.76 to 0.86 (Fox, 1971 ; E. S. Batterham and R. F. Lowe, unpublished results). If this range in values could be shown to be related to the range in lysine availability in MMs and MBMs for pigs, then the technique would be suitable for predicting availability.

Lysine availability for pigs may also be determined with slope-ratio assays using rats (Batterham et al. 1984). However, this work has shown that the technique only has application for some meals (cottonseed, soya-bean and sunflower meals) but not others (lupin-seed meal). Thus there is a need to determine if the rat assay is applicable with MMs and MBMs for pigs.

With chicks, lysine availability in the same sample of MBM was 0.86 (Major \& Batterham, 1981) indicating that chicks were more efficient in utilizing lysine in MBM than the pig. There was also closer agreement between the chick value and the indirect-FDNB

* Present address: Agricultural Research and Advisory Station, Grafton, New South Wales 2460, Australia. 
lysine assay $(0 \cdot 84)$. However, there is a need to examine a wider range of indirect-FDNB values in MMs and MBMs in order to assess the applicability of this technique for estimating lysine availability for chicks.

Processing conditions for blood meals have also been shown to affect total and chemical-'available' (direct-FDNB assay) lysine (Waibel et al. 1977) with ring-dried material being of higher quality than batch-dried material. However, the relevance of chemical estimates for 'availability' in blood meal for pigs needs to be assessed.

The present paper reports experiments that were conducted with pigs, rats and chicks to determine the availability of lysine in four MMs, four MBMs and two blood meals. The MMs and MBMs were selected to include meals of both low- and high-bone content and covered the normally recorded range of indirect-FDNB values so as to determine whether the technique could be used to predict lysine availability. The relation between slope-ratio values and the direct-FDNB assay was also determined.

\section{EXPERIMENTAL}

Wheats, wheat gluten and protein concentrates

The chemical compositions of the wheats, wheat gluten and ten protein concentrates are presented in Table 1. There were four MMs and four MBMs which ranged in indirectFDNB-'available' lysine values from 0.77 to 0.84 and 0.78 to 0.88 respectively. The two blood meals had indirect-FDNB values of 0.87 and 0.91 . The MMs and MBMs varied in calcium content from 58 to $125 \mathrm{~g} / \mathrm{kg}$ and in bone content from 256 to $540 \mathrm{~g} / \mathrm{kg}$. The MMs and MBMs were selected from both regional abattoirs and tallow manufacturers and were produced by either batch or continuous dry-rendering techniques. Both blood meals were ring-dried.

\section{Slope-ratio assays}

Slope-ratio assays were used to determine the availability of lysine in the protein concentrates for pigs, rats and chicks. For these assays, diets are formulated to contain graded levels of standard or test lysine. Linear regression coefficients of response (say food conversion efficiency) to increasing dose level of test protein and standard lysine are calculated and the ratio of the test protein's linear regression coefficient to the standard lysine's linear regression coefficient provides the potency of the lysine in the test protein. In our assays the dose levels for the test proteins were selected to contain the same total lysine as that of the standard lysine doses so that the potency estimate for lysine in the test protein was an expression of lysine availability as a proportion of total lysine.

In the statistical analyses of the slope-ratio assay, there are a number of criteria to be tested to try to ensure that the responses are due to the test amino acid and are not influenced by other dietary factors (Finney, 1964). The response to the standard amino acid is examined to determine if it passes through the basal diet (designated blanks). Similarly, the response to each test protein is examined to ensure that it passes through a common origin with the standard amino acid response (called test for intersection). The responses to both the standard amino acid and the test proteins are also examined to determine if there is any curvature (quadratic, etc.) in the responses. This could be due to either depressing (if negative curve) or stimulating (if positive curve) effects of nutrients contributed by the test protein. If the above tests are not significant, then the responses are considered statistically valid and the potency estimates calculated. The degrees of freedom used in the analyses are given by Batterham et al. (1984).

There are a number of criteria that can be used to assess response. For pigs and rats, food conversion efficiency (FCE) on a carcass basis was chosen as it takes into account 


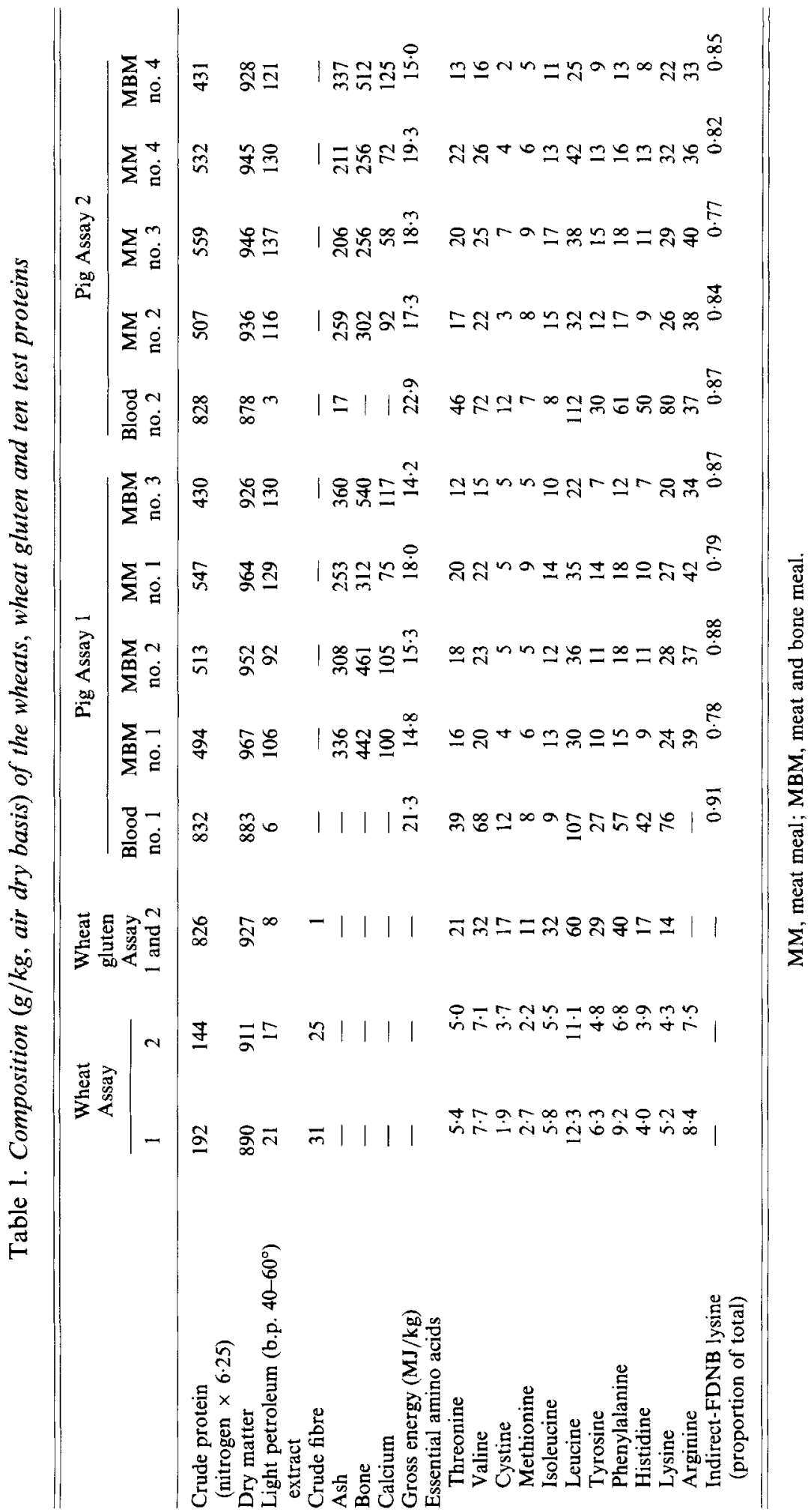


differences in both food intake and gut contents (Batterham et al. 1979, 1981, 1984). For chicks, FCE on a live-weight basis was chosen as there was no apparent advantage in expressing results on a fasted basis (Major \& Batterham, 1981).

\section{Pig slope-ratio assay}

Two multiple assays, involving five meals per assay, were conducted.

Assay 1. This assay included one blood meal, one MM and three MBMs (see Table 1).

Diets. There were thirty-two diets: the basal diet (blanks), six diets to determine the pigs' response to standard lysine and twenty-five for the five protein concentrates (five for each protein concentrate). The basal diet contained $(\mathrm{g} / \mathrm{kg})$ : wheat 830 , wheat gluten 20 , L-lysine monohydrochloride $0 \cdot 77$, DL-methionine $0 \cdot 40$, L-threonine $0 \cdot 60$, mineral and vitamin premix 5 , tricalcium phosphate 25 , wheat starch $118 \cdot 23$. The wheat was a high-protein Timgalen cultivar which, in combination with the wheat gluten, supplied adequate quantities of all the amino acids except lysine, which was added to bring the basal level up to $5.2 \mathrm{~g} / \mathrm{kg}$, and methionine and threonine, which were added to ensure adequacy according to estimates of Lewis \& Cole (1976). The six levels of lysine used to determine the pigs' response to standard lysine were in $0.5-\mathrm{g}$ increments of $\mathrm{L}-\mathrm{lysine} / \mathrm{kg}$ and were obtained by the addition to the basal diet of L-lysine monohydrochloride, anhydrous, $98 \%$ pure, supplied by Ajinomoto Co. Inc., Japan. The protein concentrates were incorporated into the diets to provide five levels of total lysine, again in $0.5 \mathrm{~g} / \mathrm{kg}$ increments, at the expense of wheat starch. The level of tricalcium phosphate was reduced to make allowance for the calcium and phosphorus in the diets containing MM or MBM. The mineral and vitamin premix contributed (/kg diet): iron $60 \mathrm{mg}$, zinc $100 \mathrm{mg}$, manganese $30 \mathrm{mg}$, copper $5 \mathrm{mg}$, iodine $2 \mathrm{mg}$, selenium $150 \mu \mathrm{g}$, sodium chloride $2.5 \mathrm{~g}$, retinol equivalent $960 \mu \mathrm{g}$, cholecalciferol $12 \mu \mathrm{g}, \alpha$-tocopherol $20 \mathrm{mg}$, thiamin $1 \mathrm{mg}$, riboflavin $3 \mathrm{mg}$, nicotinic acid $12 \mathrm{mg}$, pantothenic acid $10 \mathrm{mg}$, pyridoxine $1.5 \mathrm{mg}$, cyanocobalamin $15 \mu \mathrm{g}$, pteroylmonoglutamic acid $2 \mathrm{mg}$, choline $500 \mathrm{mg}$, ascorbic acid $10 \mathrm{mg}$ and biotin $100 \mu \mathrm{g}$.

The digestible energy content of the MMs and MBMs were estimated using prediction equations of Batterham et al. (1980). The digestible energy content of the other components was calculated using results of previous determinations at this Agricultural Research Centre or literature values. Dietary energy was maintained at $14.5 \mathrm{MJ}$ digestible energy $/ \mathrm{kg}$ diet using wheat starch and tallow as non-protein energy sources.

Animals and procedure. The pigs were blocked on 7-week weight, sex and position in the experimental facilities. There were four randomized complete blocks, two containing males and two females, all of the Large White breed. The 128 pigs were penned individually and water supplied by 'nipple' drinkers. Dietary treatments were introduced when the pigs reached $20 \mathrm{~kg}$ live weight.

The diets were offered at a daily rate of $1 \mathrm{~kg}$ at $20 \mathrm{~kg}$ live weight, with $100 \mathrm{-g}$ increments $/ 2.5 \mathrm{~kg}$ live-weight gain. The pigs were fed eight times daily, at intervals of $3 \mathrm{~h}$, with a solenoid-controlled automatic frequent feeder to ensure the utilization of added free amino acids (Batterham \& Murison, 1981). The food was offered dry. Rations were adjusted after the weekly weighings of the pigs.

The pigs were slaughtered after reaching a minimum weight of $45 \mathrm{~kg}$ and hot eviscerated carcass weights recorded. The ham was dissected and the lean content used as an indicator of carcass leanness. Pig response was assessed in terms of carcass gain $/ \mathrm{d}$ ( $\mathrm{kg}$ hot carcass weight $-(\mathrm{kg}$ initial live weight $\times 0.69) /$ period (d) on experiment $)$ and FCE on a carcass basis ( $\mathrm{kg}$ hot carcass weight $-(\mathrm{kg}$ initial live weight $\times 0.69) / \mathrm{kg}$ food intake). The factor of 0.69 for estimated initial carcass weight was previously determined with ten piglets (five males and five females) slaughtered at $20 \mathrm{~kg}$ live weight. 
The results for FCE on a carcass basis were analysed by the slope-ratio technique of Finney (1964) for multiple assays.

The results for the lean content of the hams were regressed against lysine for each protein concentrate. This analysis was conducted to determine if there was any effect of dietary lysine concentration on lean deposition.

Assay 2. This was conducted in a similar manner to Assay 1 except for a number of minor dietary changes.

Diets. The basal diet contained $(\mathrm{g} / \mathrm{kg})$ : wheat 765 , wheat gluten 70 , L-lysine monohydrochloride 1.8 , L-threonine 0.5 , mineral and vitamin premix 5 (composition as for Assay 1), arsanilic acid (feed grade) 0.5 (contributed $90 \mathrm{mg}$ arsanilic acid $/ \mathrm{kg}$ diet), dicalcium phosphate 30 , rice hulls 30 , maize oil 15 , wheat starch $82 \cdot 2$.

The wheat was of medium protein (Timgalen cultivar; composition as in Table 1) and there were only thirty-one diets (five increments of standard lysine rather than six). During Assay 1, more feed rejection than that normally encountered in previous slope-ratio assays using similar dietary formulations was experienced. In addition, performance of pigs given the blanks and the $0.5 \mathrm{~g}$ lysine supplements $/ \mathrm{kg}$ were inferior and this caused curvature within the responses (see Results section). Accordingly, in Assay 2, the dietary lysine level in the blanks was raised to $5.7 \mathrm{~g} / \mathrm{kg}$, rice hulls included to raise the fibre content of the diets, maize oil included to reduce dustiness and improve texture and arsanilic acid included. These changes were made in an attempt to stimulate appetite and to avoid curvature within responses as occurred in Assay 1.

Animals and procedure. The design of the experiment, method of procedure, assessment of performance and statistical analyses of results were as for Assay 1.

\section{Rat slope-ratio assay}

Diets. Single separate assays were conducted for each protein concentrate. A total of seven diets were used for each assay: the basal diet (blanks), three diets to determine the rats' response to standard lysine and three diets to determine the rats' response to the protein concentrate. The basal diet contained $(\mathrm{g} / \mathrm{kg})$ : wheat 650 , wheat gluten 92 , DL-methionine $0 \cdot 6$, L-threonine $0 \cdot 1$, maize oil 20 , dicalcium phosphate 25 , mineral and vitamin premix 5 (composition as for pigs), wheat starch 207.3. The combination of wheat and gluten (as used in Assay 1 for pigs; Table 1) supplied adequate levels of all amino acids except lysine $(4.7 \mathrm{~g} / \mathrm{kg})$, methionine and threonine. The latter two were added to ensure adequacy according to estimates of the (US) National Research Council (1972). The three levels of L-lysine used to determine the rats' response to standard lysine were $0.75,1.5$ and $2.25 \mathrm{~g} / \mathrm{kg}$ (same batch of lysine as used for the pig assay). The protein concentrates were incorporated into the diets to supply the same three levels of total lysine as used to determine the standard lysine response. This was done at the expense of wheat starch. The level of dicalcium phosphate was reduced to make allowance for the calcium and phosphorus in the test proteins. Additional maize oil was used with some protein concentrates to maintain the estimated digestible energy content of the diets.

Animals and procedures. For the rat assays, two female and two male albino rats, approximately 24-26-d-old, were used per dose and were blocked on the basis of litter and sex (block size seven). The rats were individually caged in a room where the temperature and relative humidity were maintained at $21 \pm 1^{\circ}$ and $50 \pm 5 \%$ respectively. Lighting was provided for $12 \mathrm{~h}$ daily. Food was supplied in 'self-feeders'.

At the completion of a $14 \mathrm{~d}$ test, the rats were weighed, killed with chloroform and the alimentary tract, heart and lungs removed. The weight of the eviscerated carcass was recorded. Performance was assessed in terms of carcass gain (g eviscerated carcass 
weight $-(\mathrm{g}$ initial live weight $\times 0.79))$ and FCE on a carcass basis ( $\mathrm{g}$ eviscerated carcass weight $-(\mathrm{g}$ initial live weight $\times 0.79) / \mathrm{g}$ food eaten $)$. The factor of 0.79 for estimated initial eviscerated carcass weight was previously determined with eight rats (four male and four female) of similar live weight and age to those used for the assays.

The results for FCE on a carcass basis were analysed by the slope-ratio technique of Finney (1964) for single assays. The assay for MBM no. 3 had a high standard error and was repeated.

\section{Chick slope-ratio assay}

Diets. Two proteins were assayed in each experiment. Ten diets were used: the basal diet (blanks), three diets to determine the chicks' response to standard lysine, and six for the two protein concentrates (three diets per protein concentrate). The basal diet contained $(\mathrm{g} / \mathrm{kg})$ : wheat 640 , wheat gluten 110 , DL-methionine $1 \cdot 5$, glycine $2 \cdot 3$, L-arginine monohydrochloride $1 \cdot 9$, sunflower oil $27 \cdot 5$, mineral and vitamin premix 6 , salt $2 \cdot 5$, tricalcium phosphate 30 , wheat starch $178 \cdot 3$. The basal diet was formulated using the same wheat and a new sample of wheat gluten of similar amino acid composition as that used for the pig and rat diets to produce a lysine-deficient $(4.9 \mathrm{~g} / \mathrm{kg})$ diet. The additional essential amino acids were added to ensure their adequacy according to the estimates of the (US) National Research Council (1971). The mineral and vitamin premix contributed the following $(/ \mathrm{kg}$ diet): manganese dioxide $96 \mathrm{mg}$, zinc oxide $60 \mathrm{mg}$, sodium molybdate $0.6 \mathrm{mg}$, cupric oxide $7.2 \mathrm{mg}$, iodine $1 \mathrm{mg}$, retinol equivalent $3.6 \mathrm{mg}$, cholecalciferol $54 \mu \mathrm{g}, \alpha$-tocopherol equivalent $3 \mathrm{mg}$, menadione-sodium bisulphite $1.4 \mathrm{mg}$, riboflavin $4.8 \mathrm{mg}$, pantothenic acid $6.6 \mathrm{mg}$, pyridoxine $4.8 \mathrm{mg}$, pteroylmonoglutamic acid $1.2 \mathrm{mg}$, nicotinic acid $24 \mathrm{mg}$, biotin $60 \mu \mathrm{g}$, cyanocobalamin $9 \mathrm{~g}$, choline chloride $120 \mathrm{mg}$, ethoxyquin $150 \mathrm{mg}$. In each experiment three levels of lysine were used to determine the chicks' response to standard lysine, which was obtained by the addition to the basal diet of L-lysine monohydrochloride (anhydrous, $98 \%$ pure; Ajinomoto Co. Inc.). The test proteins were incorporated into the basal diets to provide the same three levels of total lysine at the expense of wheat starch. The level of tricalcium phosphate was reduced to make allowance for the calcium and phosphorus in the test proteins. Dietary energy was maintained at $13 \cdot 33 \mathrm{MJ}$ metabolizable energy $/ \mathrm{kg}$ diet using wheat starch and sunflower oil as non-protein energy sources.

Animals and procedures. The ten diets were arranged in a randomized design with four cages of chicks allocated to each diet. Each cage contained seven 8-d-old female commercial broiler chicks selected for uniformity of weight after a 5 -h fast. The cages, which contained electrical brooder elements, were located in a controlled environment room maintained at $23 \pm 2^{\circ}$ and $65 \pm 5 \%$ relative humidity. Fluorescent lighting was supplied between 01,00 and 24.00 hours daily. Each cage had an individual food trough and shared a water trough with one adjacent cage. Diets, which were available at all times, were allocated at random to cages of chicks. On the morning of the 9th day on the experimental diets, the chicks and remaining food were weighed. Chick response was assessed in terms of weight gain $/ \mathrm{d}$ and FCE (g weight gain/g food intake). The results for FCE were analysed by the slope-ratio technique of Finney (1964) for multiple assays. The availabilities and their standard errors were calculated.

\section{Chemical analyses}

The techniques used were as reported by Batterham et al. (1979) except for bone (Association of Official Analytical Chemists, 1975), calcium (Hering \& Kirmas, 1974) and gross energy (Miller \& Payne, 1959). 
Table 2. Assay $1^{*}$ Carcass gain, food conversion efficiency $(F C E)$ on a carcass basis and lean content of hams of pigs during the 20-45 $\mathrm{kg}$ growth phase when fed on the diets for a slope-ratio assay for lysine

\begin{tabular}{|c|c|c|c|c|c|c|}
\hline \multirow{2}{*}{$\begin{array}{c}\text { Lysine } \\
\text { dose } \\
\text { level } \\
(\mathrm{g} / \mathrm{kg})\end{array}$} & \multicolumn{6}{|c|}{ Form of lysine addition } \\
\hline & $\begin{array}{c}\text { Free } \\
\text { lysine }\end{array}$ & $\begin{array}{l}\text { Blood } \\
\text { no. } 1\end{array}$ & $\begin{array}{c}\text { MBM } \\
\text { no. } 1\end{array}$ & $\begin{array}{c}\text { MBM } \\
\text { no. } 2\end{array}$ & $\begin{array}{l}\text { MM } \\
\text { no. } 1\end{array}$ & $\begin{array}{c}\text { MBM } \\
\text { no. } 3\end{array}$ \\
\hline \multicolumn{7}{|c|}{ Carcass gain $(\mathrm{g} / \mathrm{d}) \dagger$} \\
\hline 0 & 260 & - & - & - & - & - \\
\hline 0.5 & 312 & 330 & 336 & 326 & 309 & 357 \\
\hline 1.0 & 371 & 380 & 356 & 341 & 356 & 355 \\
\hline 1.5 & 394 & 371 & 367 & 362 & 352 & 384 \\
\hline $2 \cdot 0$ & 388 & 420 & 388 & 374 & 374 & 377 \\
\hline $2 \cdot 5$ & 423 & 397 & 375 & 402 & 380 & 365 \\
\hline \multicolumn{6}{|c|}{$\mathrm{SEM} \ddagger 13$} & - \\
\hline \multicolumn{7}{|c|}{ FCE (carcass basis) $\S$} \\
\hline 0 & 0.223 & - & - & $\ldots$ & - & $\ldots$ \\
\hline $0 \cdot 5$ & 0.248 & $0 \cdot 261$ & 0.259 & 0.260 & $0 \cdot 252$ & 0.267 \\
\hline $1 \cdot 0$ & 0.278 & 0.284 & 0.276 & 0.271 & 0.276 & 0.289 \\
\hline 1.5 & 0.297 & 0.289 & 0.280 & 0.282 & 0.273 & 0.283 \\
\hline $2 \cdot 0$ & 0.301 & 0.309 & 0.291 & 0.294 & 0.284 & 0.297 \\
\hline $2 \cdot 5$ & 0.311 & 0.312 & 0.296 & 0.303 & 0.286 & 0.286 \\
\hline $3 \cdot 0$ & 0.323 & - & - & - & - & - \\
\hline \multicolumn{7}{|c|}{ SEM 0.007} \\
\hline \multicolumn{7}{|c|}{ Lean in ham $(\mathrm{g} / \mathrm{kg})$} \\
\hline 0 & 602 & - & - & 一 & - & - \\
\hline 0.5 & 607 & 618 & 605 & 604 & 609 & 590 \\
\hline $1 \cdot 0$ & 597 & 625 & 604 & 596 & 604 & 638 \\
\hline 1.5 & 620 & 625 & 595 & 618 & 638 & 629 \\
\hline $2 \cdot 0$ & 640 & 620 & 620 & 622 & 614 & 634 \\
\hline $2 \cdot 5$ & 628 & 642 & 617 & 614 & 605 & 636 \\
\hline $3 \cdot 0$ & 640 & - & - & - & - & - \\
\hline \multicolumn{7}{|c|}{ SEM 12} \\
\hline
\end{tabular}

MBM, meat and bone meal; MM, meat meal.

* For details, see p. 430.

$\dagger$ Hot carcass weight $(\mathrm{kg})$ - (initial live weight $(\mathrm{kg}) \times 0.69) /$ period $(\mathrm{d})$ on experiment.

$\ddagger$ Based on 95 degrees of freedom.

$\S$ Hot carcass weight $(\mathrm{kg})$ - (initial live weight $(\mathrm{kg}) \times 0.69) /$ food intake $(\mathrm{kg})$.

\section{RESULTS}

Pigs. Performance results of the pigs for Assays 1 and 2 are presented in Tables 2 and 3 respectively. One pig died in Assay 1 (blood meal diet, $1 \mathrm{~g}$ lysine inclusion $/ \mathrm{kg}$ diet) with post-mortem symptoms of a viral infection. Another pig in Assay 1, fed on MBM no. 2 $(2.5 \mathrm{~g}$ lysine inclusion $/ \mathrm{kg})$, performed very poorly and its results were deleted from the slope-ratio analysis. There was a fair degree of food rejection by most pigs in Assay 1 and lesser amounts by pigs in Assay 2.

Lean in the ham of pigs increased slightly as the level of dietary lysine increased in both experiments and there were no significant differences between the slopes for each protein concentrate and the standard lysine responses.

With Assay 1, blanks and curvature were significant $(P<0.05)$ in the statistical analysis of the standard lysine response and with most meals. An examination of the performance 
Table 3. Assay 2*. Carcass gain, food conversion efficiency $(F C E)$ on a carcass basis and lean content of hams of pigs during the 20-45 $\mathrm{kg}$ growth phase when fed on the diets for a slope-ratio assay for lysine

\begin{tabular}{|c|c|c|c|c|c|c|}
\hline \multirow{2}{*}{$\begin{array}{c}\text { Lysine } \\
\text { dose } \\
\text { level } \\
(\mathrm{g} / \mathrm{kg})\end{array}$} & \multicolumn{6}{|c|}{ Form of lysine addition } \\
\hline & $\begin{array}{c}\text { Free } \\
\text { lysine }\end{array}$ & $\begin{array}{l}\text { Blood } \\
\text { no. } 2\end{array}$ & $\begin{array}{l}\text { MM } \\
\text { no. } 2\end{array}$ & $\begin{array}{l}\text { MM } \\
\text { no. } 3\end{array}$ & $\begin{array}{c}\text { MM } \\
\text { no. } 4\end{array}$ & $\begin{array}{c}\text { MBM } \\
\text { no. } 4\end{array}$ \\
\hline \multicolumn{7}{|c|}{ Carcass gain $(\mathrm{g} / \mathrm{d}) \dagger$} \\
\hline 0 & 350 & - & - & - & -- & - \\
\hline 0.5 & 406 & 415 & 359 & 356 & 396 & 422 \\
\hline 1.0 & 403 & 420 & 402 & 414 & 387 & 433 \\
\hline $1 \cdot 5$ & 405 & 409 & 418 & 429 & 445 & 431 \\
\hline $2 \cdot 0$ & 470 & 473 & 422 & 465 & 437 & 452 \\
\hline $2 \cdot 5$ & 470 & 476 & 430 & 443 & 448 & 434 \\
\hline \multicolumn{7}{|c|}{ SEM $\ddagger 14$} \\
\hline \multicolumn{7}{|c|}{ FCE (carcass basis) $\S$} \\
\hline 0 & $0 \cdot 261$ & - & - & $\ldots$ & - & - \\
\hline $0 \cdot 5$ & $0 \cdot 302$ & $0 \cdot 305$ & $0 \cdot 269$ & $0 \cdot 275$ & 0.294 & 0.308 \\
\hline $1 \cdot 0$ & $0 \cdot 301$ & 0.310 & 0.299 & 0.304 & 0.291 & 0.321 \\
\hline 1.5 & 0.304 & 0.305 & 0.305 & 0.316 & 0.323 & 0.314 \\
\hline $2 \cdot 0$ & $0 \cdot 340$ & 0.345 & 0.313 & 0.339 & 0.322 & 0.329 \\
\hline $2 \cdot 5$ & $0 \cdot 347$ & $0 \cdot 356$ & 0.319 & 0.326 & $0 \cdot 338$ & 0.324 \\
\hline \multicolumn{7}{|c|}{ SEM 0.009} \\
\hline \multicolumn{7}{|c|}{ Lean in ham $(\mathrm{g} / \mathrm{kg})$} \\
\hline 0 & 613 & - & - & - & - & - \\
\hline 0.5 & 594 & 617 & 608 & 602 & 592 & 592 \\
\hline $1 \cdot 0$ & 619 & 632 & 594 & 616 & 612 & 618 \\
\hline 1.5 & 612 & 645 & 626 & 608 & 636 & 619 \\
\hline $2 \cdot 0$ & 617 & 613 & 603 & 643 & 609 & 626 \\
\hline $2 \cdot 5$ & 630 & 616 & 622 & 645 & 624 & 638 \\
\hline \multicolumn{7}{|c|}{ SEM 15} \\
\hline
\end{tabular}

MM, meat meal; MBM, meat and bone meal.

* For details, see p. 431.

$\dagger$ Hot carcass weight $(\mathrm{kg})-$ (initial live weight $(\mathrm{kg}) \times 0.69) /$ period $(\mathrm{d})$ on experiment.

* Based on 93 degrees of freedom.

$\S$ Hot carcass weight $(\mathrm{kg})$ - (initial live weight $(\mathrm{kg}) \times 0.69) /$ food intake $(\mathrm{kg})$.

results indicated lower performance in animals given the blanks and the $0.5 \mathrm{~g}$ lysine inclusion $/ \mathrm{kg}$ diet for the standard lysine response and for all meals. Accordingly, these levels were deleted from the slope-ratio analysis and the potency estimates then determined were statistically valid for all meals except MBM no. 3, where intersection was significant $(P<0.05)$ (Table 9, p. 439). With Assay 2, all estimates were statistically valid except MBM no. 4 , where intersection was significant $(P<0.01$; Table 9$)$.

Availability of lysine in the MMs and MBMs varied from 0.48 to 0.88 . With blood meal, availability varied from 1.03 to 1.13 .

Rats. Performance results for the rats are presented in Tables 4-6 and the slope-ratio values in Table 9 (p. 439). Availability estimates for the two assays for MBM no. 3 were 0.90 (SEM 0.16 ) and 0.87 (SEM 0.12 ) respectively. Only the mean values for the two assays are presented in Table 9.

Lysine availability in the MMs and MBMs for rats varied from 0.49 to 0.88 . There was no apparent relation between the rat and pig estimates.

Rat slope-ratio values for the two blood meals were 0.81 and 0.80 and were lower than the pig estimates. 
Table 4. Carcass gain $(\mathrm{g} / 14 \mathrm{~d})$ and food conversion efficiency $(F C E)$ on a carcass basis of rats fed on the diets for the slope-ratio assay for lysine in meat meal (MM)

\begin{tabular}{|c|c|c|c|c|c|c|}
\hline \multirow{2}{*}{$\begin{array}{c}\text { Assay } \\
\text { no. }\end{array}$} & \multirow{2}{*}{$\begin{array}{c}\text { Test } \\
\text { protein }\end{array}$} & \multirow{2}{*}{$\begin{array}{l}\text { Index of } \\
\text { response }\end{array}$} & \multicolumn{4}{|c|}{ Lysine dose level $(\mathrm{g} / \mathrm{kg})$} \\
\hline & & & 0 & 0.75 & 1.50 & 2.25 \\
\hline \multirow[t]{6}{*}{1} & Free lysine & Gain* & $23 \cdot 4$ & $28 \cdot 1$ & $40 \cdot 4$ & $42 \cdot 4$ \\
\hline & MM no. 1 & & - & 28.9 & 31.9 & $37 \cdot 0$ \\
\hline & & & \multicolumn{4}{|c|}{ SEM $^{\dagger} 1.85$} \\
\hline & Free lysine & FCE $\ddagger$ & $0 \cdot 169$ & 0.219 & 0.252 & 0.267 \\
\hline & MM no. 1 & & - & 0.203 & 0.224 & 0.255 \\
\hline & & & \multicolumn{4}{|c|}{ SEM $0 \cdot 0080$} \\
\hline \multirow[t]{6}{*}{2} & Free lysine & Gain & $25 \cdot 4$ & $34 \cdot 5$ & $45 \cdot 6$ & $48 \cdot 0$ \\
\hline & MM no. 2 & & - & $29 \cdot 3$ & $38 \cdot 1$ & $39 \cdot 1$ \\
\hline & & & \multicolumn{4}{|c|}{ SEM 2.03} \\
\hline & Free lysine & FCE & $0 \cdot 165$ & 0.202 & 0.258 & 0.273 \\
\hline & MM no. 2 & & - & $0 \cdot 183$ & 0.227 & 0.233 \\
\hline & & & \multicolumn{4}{|c|}{ SEM 0.0089} \\
\hline \multirow[t]{6}{*}{3} & Free lysine & Gain & $26 \cdot 3$ & 34.9 & $45 \cdot 5$ & $46 \cdot 3$ \\
\hline & MM no. 3 & & - & $32 \cdot 1$ & $34 \cdot 9$ & $35 \cdot 6$ \\
\hline & & & \multicolumn{4}{|c|}{ SEM 1.95} \\
\hline & Free lysine & FCE & $0 \cdot 170$ & 0.207 & $0 \cdot 245$ & 0.261 \\
\hline & MM no. 3 & & - & $0 \cdot 197$ & $0 \cdot 207$ & 0.218 \\
\hline & & & \multicolumn{4}{|c|}{ SEM 0.0114} \\
\hline \multirow[t]{6}{*}{4} & Free lysine & Gain & $29 \cdot 1$ & $37 \cdot 0$ & $43 \cdot 7$ & 54.4 \\
\hline & MM no. 4 & & - & $35 \cdot 4$ & 39.9 & $46 \cdot 0$ \\
\hline & & & \multicolumn{4}{|c|}{ SEM $3 \cdot 16$} \\
\hline & Free lysine & FCE & $0 \cdot 183$ & & 0.248 & 0.288 \\
\hline & MM no. 4 & & - & 0.213 & $0 \cdot 224$ & 0.262 \\
\hline & & & \multicolumn{4}{|c|}{ SEM 0.0094} \\
\hline
\end{tabular}

* Eviscerated carcass weight $(\mathrm{g})-$ (initial weight $(\mathrm{g}) \times 0 \cdot 79)$.

$\dagger$ Based on twenty-one degrees of freedom.

$\mp$ Eviscerated carcass weight $(\mathrm{g})-$ (initial weight $(\mathrm{g}) \times 0 \cdot 79) /$ food intake $(\mathrm{g})$.

Chicks. Performance results for the chicks are presented in Tables 7 and 8 and the slope-ratio values in Table 9. Lysine availability in the MMs and MBMs for chicks varied from 0.68 to 0.88 . There was no apparent relation between the chick and pig or rat estimates.

The chick slope-ratio values for the two blood meals were 1.07 and 1.02 which were similar to the pig estimates but higher than those of the rat.

Chemical. There was no apparent relation between the indirect- and direct-FDNB values and the pig slope-ratio values (Table 9). For rats and chicks, there may have been some relation but there were insufficient assays to show this clearly.

With blood meals, both the indirect- and direct-FDNB values were slightly higher than the slope-ratio values for rats but slightly lower than the pig and chick values.

\section{DISCUSSION}

The results indicate considerable variation in the availability of lysine in MMs and MBMs for pigs, rats and chicks. This variation appeared unrelated to the chemical composition of the meals, and MBMs with high-bone contents had similarly high lysine availabilities as MMs of lower bone and higher crude protein contents. This indicates that variability in lysine availability is independent of starting material and most probably reflects processing conditions. However, total lysine content appeared dependent on chemical 
Table 5. Carcass gain $(\mathrm{g} / 14 \mathrm{~d})$ and food conversion efficiency $(F C E)$ on a carcass basis of rats fed on the diets for the slope-ratio assay for lysine in meat and bone meal (MBM)

\begin{tabular}{|c|c|c|c|c|c|c|}
\hline \multirow{2}{*}{$\begin{array}{l}\text { Assay } \\
\text { no. }\end{array}$} & \multirow{2}{*}{$\begin{array}{c}\text { Test } \\
\text { protein }\end{array}$} & \multirow{2}{*}{$\begin{array}{l}\text { Index } \\
\text { of response }\end{array}$} & \multicolumn{4}{|c|}{ Lysine dose level $(\mathrm{g} / \mathrm{kg})$} \\
\hline & & & 0 & $0 \cdot 75$ & $1 \cdot 50$ & $2 \cdot 25$ \\
\hline \multirow[t]{6}{*}{5} & Free lysine & Gain* & $26 \cdot 4$ & $33 \cdot 6$ & 38.5 & $48 \cdot 4$ \\
\hline & MBM no. 1 & & - & $27 \cdot 4$ & $38 \cdot 1$ & $40 \cdot 3$ \\
\hline & & & \multicolumn{4}{|c|}{ SEM $† 2.48$} \\
\hline & Free lysine & FCE $\ddagger$ & $0 \cdot 178$ & 0.214 & $0 \cdot 256$ & 0.284 \\
\hline & MBM no. 1 & & - & 0.201 & 0.233 & $0 \cdot 247$ \\
\hline & & & \multicolumn{4}{|c|}{ SEM 0.0061} \\
\hline \multirow[t]{6}{*}{6} & Free lysine & Gain & $27 \cdot 3$ & $37 \cdot 3$ & $44 \cdot 0$ & $48 \cdot 3$ \\
\hline & MBM no. 2 & & - & $30 \cdot 8$ & $41 \cdot 1$ & $44 \cdot 8$ \\
\hline & & & \multicolumn{4}{|c|}{ SEM 2.77} \\
\hline & Free lysine & FCE & $0 \cdot 177$ & $0 \cdot 228$ & 0.255 & $0 \cdot 288$ \\
\hline & MBM no. 2 & & - & $0 \cdot 194$ & 0.243 & 0.268 \\
\hline & & & \multicolumn{4}{|c|}{ SEM 0.0089} \\
\hline \multirow[t]{6}{*}{7} & Free lysine & Gain & $23 \cdot 8$ & $33 \cdot 5$ & $40 \cdot 0$ & $48 \cdot 0$ \\
\hline & MBM no. 3 & & - & $30 \cdot 4$ & $41 \cdot 0$ & 40.0 \\
\hline & & & \multicolumn{4}{|c|}{ SEM 2.36} \\
\hline & Free lysine & FCE & $0 \cdot 159$ & $0 \cdot 208$ & 0.243 & 0.267 \\
\hline & MBM no. 3 & & - & 0.206 & 0.249 & $0 \cdot 248$ \\
\hline & & & \multicolumn{4}{|c|}{ SEM 0.0146} \\
\hline \multirow[t]{6}{*}{8} & Free lysine & Gain & $25 \cdot 0$ & $32 \cdot 4$ & $43 \cdot 4$ & $45 \cdot 4$ \\
\hline & MBM no. 3 & & - & $30 \cdot 5$ & 38.6 & $40 \cdot 5$ \\
\hline & & & \multicolumn{4}{|c|}{ SEM 2.41} \\
\hline & Free lysine & FCE & $0 \cdot 152$ & $0 \cdot 191$ & 0.228 & 0.246 \\
\hline & MBM no. 3 & & - & $0 \cdot 188$ & 0.219 & 0.236 \\
\hline & & & \multicolumn{4}{|c|}{ SEM 0.0111 } \\
\hline \multirow[t]{6}{*}{9} & Free lysine & Gain & $27 \cdot 4$ & $35 \cdot 2$ & $44 \cdot 7$ & $48 \cdot 3$ \\
\hline & MBM no. 4 & & - & $34 \cdot 1$ & $39 \cdot 8$ & $43 \cdot 2$ \\
\hline & & & \multicolumn{4}{|c|}{ SEM 2.90} \\
\hline & Free lysine & FCE & $0 \cdot 172$ & 0.213 & 0.244 & 0.267 \\
\hline & MBM no. 4 & & - & 0.196 & 0.222 & 0.246 \\
\hline & & & \multicolumn{4}{|c|}{ SEM 0.0097 } \\
\hline
\end{tabular}

* Eviscerated carcass weight $(\mathrm{g})-$ (initial weight $(\mathrm{g}) \times 0.79)$.

+ Based on twenty-one degrees of freedom.

$\ddagger$ Eviscerated carcass weight $(\mathrm{g})-$ (initial weight $(\mathrm{g}) \times 0.79) /$ food intake $(\mathrm{g})$.

composition with meals of low ash content having higher total lysine levels than meals of high ash content.

The curvature in responses in Assay 1 for pigs is interpreted as due to the pigs having a higher lysine requirement than those used in previous experiments. The reason for this is unclear. The experiment was conducted during the summer period when maximum daily pen temperatures approached $30^{\circ}$. It is possible that the pigs had a slightly higher lysine/energy requirement as less energy would be required for maintenance of body temperature. Curvature in response was not a problem in Expt 2 but it was conducted during the autumn period (maximum daily temperatures seldom above $25^{\circ}$ ) and a higher lysine content in the basal diet $(5.7$ instead of $5.2 \mathrm{~g} / \mathrm{kg})$.

The use of carcass gain to assess response assumes that lean deposition is similar for all treatments or, if it is affected, then the rate of change is similar for all test proteins. In these experiments, carcass lean, as indicated by lean in the ham, increased with increasing lysine level. However, the rate of increase was similar for all test proteins, thus indicating that 
Table 6. Weight gain $(\mathrm{g} / \mathrm{l4} \mathrm{d})$ and food conversion efficiency $(F C E)$ on a carcass basis of rats fed on the diets for the slope-ratio assay for lysine in blood meals

\begin{tabular}{|c|c|c|c|c|c|c|}
\hline \multirow{2}{*}{$\begin{array}{l}\text { Assay } \\
\text { no. }\end{array}$} & \multirow{2}{*}{$\begin{array}{c}\text { Test } \\
\text { protein }\end{array}$} & \multirow{2}{*}{$\begin{array}{l}\text { Index } \\
\text { of response }\end{array}$} & \multicolumn{4}{|c|}{ Lysine dose level $(\mathrm{g} / \mathrm{kg})$} \\
\hline & & & 0 & 0.75 & $1 \cdot 50$ & $2 \cdot 25$ \\
\hline \multirow[t]{4}{*}{10} & Free lysine & Gain* & $30 \cdot 8$ & $36 \cdot 5$ & 41.9 & 48.9 \\
\hline & Free lysine & FCE $\ddagger$ & 0.193 & 0.229 & 0.256 & $0 \cdot 291$ \\
\hline & Blood meal no. 1 & & - & 0.223 & 0.237 & 0.277 \\
\hline & & & \multicolumn{4}{|c|}{ SEM 0.0129} \\
\hline \multirow[t]{6}{*}{11} & Free lysine & Gain & $25 \cdot 1$ & $34 \cdot 7$ & $41 \cdot 8$ & $47 \cdot 7$ \\
\hline & Blood meal no. 2 & & - & $30 \cdot 4$ & $36 \cdot 7$ & $42 \cdot 6$ \\
\hline & & & \multicolumn{4}{|c|}{ SEM 2.07} \\
\hline & Free lysine & FCE & $0 \cdot 163$ & 0.212 & $0 \cdot 247$ & 0.269 \\
\hline & Blood meal no. 2 & & -- & $0 \cdot 194$ & 0.239 & $0 \cdot 248$ \\
\hline & & & \multicolumn{4}{|c|}{ SEM 0.0112} \\
\hline
\end{tabular}

* Eviscerated carcass weight $(\mathrm{g})-$ (initial weight $(\mathrm{g}) \times 0 \cdot 79$ )

$\dagger$ Based on twenty-one degrees of freedom.

$\ddagger$ Eviscerated carcass weight $(\mathrm{g})-$ (initial weight $(\mathrm{g}) \times 0.79) /$ food intake $(\mathrm{g})$.

carcass gain was an adequate measure of protein deposition. Similarly, although there was some food rejection in Assay 1, the use of FCE on a carcass basis as the index of response has the advantage that it takes into account any variation in food intake between treatments.

Although the ranges in lysine availabilities in MMs and MBMs for pigs and rats were similar, there was no relation between the individual values for the two species. This suggests that different mechanisms were affecting lysine availability within the meals. A similar lack of agreement in lysine availability between pigs and rats for lupin-seed meal was reported by Batterham et al. (1984).

With chicks, the range in lysine availabilities in the MMs and MBMs was less than that for pigs and rats but there was no overall relation between estimates for individual meals. These results confirm the findings of Major \& Batterham (1981) that chicks are more efficient in utilizing lysine in some samples of MM or MBM than pigs and rats. As with rats, the chick appeared more sensitive to changes involving the free $\epsilon$-amino group of lysine than the pig. However, overall the relation between the chemical techniques and the rat and chick results was small, if it existed at all, and the inconsistency between species indicates that different mechanisms may be inhibiting the availability of lysine in the meals for the different species.

The close agreement between the values for the indirect- and direct-FDNB values in the MMs and MBMs would be expected as there was little carbohydrate in these meals. It is only in meals of high-carbohydrate content that instability of the dinitrophenylysine becomes a problem with the direct-FDNB assay, leading to underestimation of availability (Batterham et al. 1984).

The high availability of lysine in ring-dried blood meal for pigs and chicks confirms the findings of Waibel et al. (1977). The reason for the estimate being slightly greater than the one for pigs and chicks may reflect either a systematic error or variation in the estimates as their standard deviations were high. With rats, the lower estimate of approximately $0 \cdot 80$ has been confirmed with additional meals and again indicates species differences in ability to utilize lysine within particular meals. A greater range of values in lysine availability in 
Table 7. Weight gain $(\mathrm{g} / \mathrm{d})$ and food conversion efficiency $(F C E)$ of chicks fed on the diets for the slope-ratio assay for lysine in meat meal (MM) and meat and bone meal (MBM)

\begin{tabular}{|c|c|c|c|c|c|c|}
\hline \multirow{2}{*}{$\begin{array}{c}\text { Assay } \\
\text { no. }\end{array}$} & \multirow{2}{*}{$\begin{array}{c}\text { Test } \\
\text { protein }\end{array}$} & \multirow{2}{*}{$\begin{array}{l}\text { Index } \\
\text { of response }\end{array}$} & \multicolumn{4}{|c|}{ Lysine dose level $(\mathrm{g} / \mathrm{kg})$} \\
\hline & & & 0 & $1 \cdot 10$ & $2 \cdot 2 \mathrm{I}$ & $3 \cdot 31$ \\
\hline \multirow[t]{8}{*}{1} & Free lysine & Gain & $4 \cdot 36$ & 7.04 & $10 \cdot 28$ & 13.00 \\
\hline & MM no. 1 & & - & $6 \cdot 22$ & 6.97 & $9 \cdot 26$ \\
\hline & MBM no. 1 & & - & $5 \cdot 82$ & 7.89 & 9.56 \\
\hline & & & \multicolumn{4}{|c|}{ SEM $\dagger 0.54$} \\
\hline & Free lysine & FCE* & 0.310 & 0.398 & 0.486 & 0.565 \\
\hline & MM no. 1 & & - & 0.373 & $0 \cdot 415$ & 0.492 \\
\hline & MBM no. 1 & & -- & $0 \cdot 379$ & 0.449 & $0 \cdot 502$ \\
\hline & & & \multicolumn{4}{|c|}{ SEM 0.0075} \\
\hline \multirow[t]{10}{*}{2} & Free lysine & Gain & 4.08 & 5.94 & $8 \cdot 28$ & $11 \cdot 35$ \\
\hline & MM no. 2 & & - & $5 \cdot 44$ & $7 \cdot 19$ & $8 \cdot 41$ \\
\hline & MBM no. 2 & & - & $6 \cdot 20$ & $7 \cdot 10$ & $9 \cdot 44$ \\
\hline & & & \multicolumn{4}{|c|}{ SEM 0.57} \\
\hline & Free lysine & FCE & $0 \cdot 301$ & $0 \cdot 378$ & $0 \cdot 464$ & $0 \cdot 553$ \\
\hline & MM no. 2 & & - & $0 \cdot 360$ & $0 \cdot 440$ & 0.475 \\
\hline & MBM no. 2 & & - & 0.400 & 0.439 & 0.511 \\
\hline & & & \multicolumn{4}{|c|}{ SEM 0.011} \\
\hline & & & \multicolumn{4}{|c|}{ Lysine dose level (g/kg) } \\
\hline & & & 0 & 0.82 & 1.65 & $2 \cdot 48$ \\
\hline \multirow[t]{10}{*}{3} & Free lysine & Gain & $5 \cdot 81$ & $7 \cdot 44$ & $9 \cdot 90$ & $12 \cdot 82$ \\
\hline & MM no. 3 & & - & $7 \cdot 26$ & $8 \cdot 38$ & $10 \cdot 29$ \\
\hline & MBM no. 3 & & - & $7 \cdot 83$ & $9 \cdot 58$ & $10 \cdot 13$ \\
\hline & & & \multicolumn{4}{|c|}{ SEM 0.45} \\
\hline & Free lysine & FCE & 0.328 & 0.402 & 0.463 & 0.521 \\
\hline & MM no. 3 & & - & 0.382 & 0.426 & 0.483 \\
\hline & MBM no. 3 & & - & 0.398 & 0.446 & 0.486 \\
\hline & & & \multicolumn{4}{|c|}{ SEM 0.0099} \\
\hline & & & \multicolumn{4}{|c|}{ Lysine dose level $(\mathrm{g} / \mathrm{kg})$} \\
\hline & & & 0 & 0.94 & 1.88 & $2 \cdot 83$ \\
\hline \multirow[t]{8}{*}{4} & Free lysine & Gain & $4 \cdot 86$ & $6 \cdot 73$ & $10 \cdot 17$ & $12 \cdot 56$ \\
\hline & MM no. 4 & & - & $5 \cdot 58$ & $7 \cdot 63$ & $9 \cdot 56$ \\
\hline & MBM no. 4 & & - & $6 \cdot 04$ & $8 \cdot 01$ & $10 \cdot 26$ \\
\hline & & & \multicolumn{4}{|c|}{ SEM $0 \cdot 50$} \\
\hline & Free lysine & FCE & 0.322 & 0.398 & 0.475 & 0.538 \\
\hline & MM no. 4 & & - & 0.362 & 0.430 & 0.480 \\
\hline & MBM no. 4 & & - & 0.376 & 0.452 & 0.518 \\
\hline & & & \multicolumn{4}{|c|}{ SEM 0.0083} \\
\hline
\end{tabular}

* Weight gain (g)/food intake (g).

+ Based on thirty degrees of freedom.

blood meal is needed before an assessment of the usefulness of the chemical techniques for assessing available lysine can be made.

Overall, the results indicate considerable variation in the availability of lysine in MMs and MBMs for pigs, rats and chicks which may reflect variation in processing conditions. The lack of agreement between the three species for individual meals indicates a species difference in ability to utilize lysine. The results also indicate no apparent relation between the values for the two chemical 'available' lysine techniques and the pig results. There were insufficient results to indicate whether or not such a relation existed for rats and chicks. 
Table 8. Weight gain $(\mathrm{g} / \mathrm{d})$ and food conversion efficiency $(F C E)$ of chicks fed on the diets for the slope-ratio assay for lysine in blood meals

\begin{tabular}{|c|c|c|c|c|c|c|}
\hline \multirow{2}{*}{$\begin{array}{l}\text { Assay } \\
\text { no. }\end{array}$} & \multirow{2}{*}{$\begin{array}{c}\text { Test } \\
\text { protein }\end{array}$} & \multirow{2}{*}{$\begin{array}{l}\text { Index } \\
\text { of response }\end{array}$} & \multicolumn{4}{|c|}{ Lysine dose level $(\mathrm{g} / \mathrm{kg})$} \\
\hline & & & 0 & $1 \cdot 17$ & $2 \cdot 33$ & $3 \cdot 50$ \\
\hline \multirow[t]{7}{*}{5} & $\begin{array}{l}\text { Free lysine } \\
\text { Blood meal no. } 1\end{array}$ & Gain & $4 \cdot 42$ & $\begin{array}{l}5 \cdot 81 \\
6 \cdot 03\end{array}$ & $\begin{array}{l}8.58 \\
8.65\end{array}$ & $\begin{array}{l}11 \cdot 22 \\
10 \cdot 56\end{array}$ \\
\hline & & & \multicolumn{4}{|c|}{ SEM+ 0.62} \\
\hline & Free lysine & FCE* & 0.326 & $0 \cdot 380$ & 0.457 & 0.551 \\
\hline & Blood meal no. 1 & & - & 0.395 & 0.477 & 0.559 \\
\hline & & & \multicolumn{4}{|c|}{$\operatorname{SEM} 0.010$} \\
\hline & & & \multicolumn{4}{|c|}{ Lysine dose level $(\mathrm{g} / \mathrm{kg})$} \\
\hline & & & 0 & $1 \cdot 10$ & $2 \cdot 19$ & $3 \cdot 29$ \\
\hline \multirow[t]{6}{*}{6} & Free lysine & Gain & $4 \cdot 24$ & $6 \cdot 41$ & $8 \cdot 58$ & $11 \cdot 39$ \\
\hline & Blood meal no. 2 & & - & $6 \cdot 33$ & 8.45 & $11 \cdot 35$ \\
\hline & & & \multicolumn{4}{|c|}{ SEM 0.48} \\
\hline & Free lysine & FCE & $0 \cdot 317$ & 0.381 & 0.456 & 0.545 \\
\hline & Blood meal no. 2 & & - & 0.400 & 0.463 & 0.542 \\
\hline & & & \multicolumn{4}{|c|}{ SEM 0.0085} \\
\hline
\end{tabular}

* Weight gain (g)/food intake (g).

$\dagger$ Based on thirty degrees of freedom.

Table 9. Availability of lysine (proportion of total) in the test proteins as assessed by the indirect-FDNB (Roach et al. 1967), the direct-FDNB assay (Carpenter, 1960) and by the slope-ratio assay with pigs, rats and chicks

(Mean values with their standard errors)

\begin{tabular}{|c|c|c|c|c|c|c|c|c|}
\hline \multirow{3}{*}{$\begin{array}{c}\text { Test } \\
\text { protein }\end{array}$} & \multirow{3}{*}{$\begin{array}{c}\text { Indirect- } \\
\text { FDNB } \\
\text { assay }\end{array}$} & \multirow{3}{*}{$\begin{array}{l}\text { Direct- } \\
\text { FDNB } \\
\text { assay }\end{array}$} & \multicolumn{6}{|c|}{ Slope-ratio assay } \\
\hline & & & \multicolumn{2}{|c|}{ Pigs } & \multicolumn{2}{|c|}{ Rats } & \multicolumn{2}{|c|}{ Chicks } \\
\hline & & & Mean & SEM & Mean & SEM & Mean & SEM \\
\hline MM no. 1 & 0.79 & $0 \cdot 80$ & $0 \cdot 48$ & 0.05 & 0.68 & 0.07 & 0.68 & 0.03 \\
\hline MM no. 2 & 0.84 & 0.90 & 0.59 & 0.05 & 0.62 & 0.08 & 0.73 & 0.05 \\
\hline MM no. 3 & 0.77 & 0.78 & $0 \cdot 87$ & 0.06 & 0.49 & 0.12 & 0.76 & 0.06 \\
\hline MM no. 4 & $0 \cdot 82$ & 0.84 & $0 \cdot 88$ & 0.06 & $0 \cdot 74$ & 0.09 & $0 \cdot 71$ & 0.04 \\
\hline MBM no. 1 & $0 \cdot 78$ & 0.79 & 0.66 & 0.05 & 0.67 & 0.06 & $0 \cdot 76$ & 0.03 \\
\hline MBM no. 2 & 0.88 & 0.93 & 0.74 & 0.06 & 0.78 & 0.08 & 0.86 & 0.05 \\
\hline MBM no. 3 & 0.87 & 0.93 & $\ldots$ & - & 0.88 & $0 \cdot 10$ & 0.83 & 0.06 \\
\hline MBM no. 4 & $0 \cdot 85$ & 0.92 & 一* $^{*}$ & - & 0.73 & 0.09 & 0.88 & 0.04 \\
\hline Blood no. 1 & 0.91 & 0.97 & $1 \cdot 03$ & 0.08 & $0 \cdot 81$ & $0 \cdot 13$ & $1 \cdot 07$ & 0.05 \\
\hline Blood no. 2 & $0 \cdot 87$ & $0 \cdot 88$ & $1 \cdot 13$ & $0 \cdot 07$ & $0 \cdot 80$ & 0.11 & 1.02 & 0.04 \\
\hline
\end{tabular}

FDNB, 1-fluoro-2,4-dinitrobenzene; MM, meat meal; MBM, meat and bone meal.

* Slope-ratio estimates not calculated as intersection significant $(P<0.05)$.

The authors thank Mrs L. M. Andersen and Messrs N. R. Thompson, A. W. Davis and H. M. Essery for skilled technical assistance. This work was supported by financial grants from the Australian Pig Industry Research Committee and the Australian Chicken Meat Research Committee. 


\section{REFEREN CES}

Association of Official Analytical Chemists (1975). Official Methods of Analysis of the Association of Official Analytical Chemists, 12th ed. Washington, DC: Association of Official Analytical Chemists.

Batterham, E. S., Lewis, C. E., Lowe, R. F. \& McMillian, C. J. (1980). Animal Production 31, 273-277.

Batterham, E. S. \& Murison, R. D. (1981). British Journal of Nutrition 46, 87-92.

Batterham, E. S., Murison, R. D. \& Andersen, L. M. (1984). British Journal of Nutrition 51, 85-99.

Batterham, E. S., Murison, R. D. \& Lewis, C. E. (1978). British Journal of Nutrition 40, 23-28.

Batterham, E. S., Murison, R. D. \& Lewis, C. E. (1979). British Journal of Nutrition 41, 383-391.

Batterham, E. S., Murison, R. D. \& Lowe, R. F. (1981). British Journal of Nutrition 45, 401-410.

Carpenter, K. J. (1960). Biochemical Journal 77, 604-610.

Finney, D. J. (1964). Statistical Method in Biological Assay, 2nd ed. London: Griffin.

Fox, M. (1971). Division of Agricultural Chemistry Report no. 2. Victoria, Australia: Division of Agricultural Chemistry, Department of Agriculture.

Hering, D. \& Kirmas, D. (1974). Die Dahrung 18, 775-782.

Lewis, D. \& Cole, D. J. A. (1976). Proceedings of the Nutrition Society 35, 87-91.

Major, E. J. \& Batterham, E. S. (1981). British Journal of Nutrition 46, 513-519.

Miller, D. S. \& Payne, P. R. (1959). British Journal of Nutrition 13, 501-508.

National Research Council (1971). Nutrient Requirements of Poultry, 6th ed. Washington, DC: National Academy of Sciences.

National Research Council (1972). Nutrient Requirements of Laboratory Animals, 2nd ed. Washington, DC: National Academy of Sciences.

Roach, A. G., Sanderson, P. \& Williams, D. R. (1967). Journal of the Science of Food and Agriculture 18, $274-278$.

Waibel, P. E., Cuperlovic, M., Hurrell, R. F. \& Carpenter, K. J. (1977). Journal of Agriculture, Food and Chemistry 25, 171-175. 